\title{
Relation between epicardial fat tissue and atrial fibrillation
}

\author{
Epikardiyal yağ doku ve atriyal fibrilasyon arasındaki ilişsi
}

\author{
Mustafa Kurt ${ }^{1}$, Ibrahim Halil Tanboğa ${ }^{1}$, Enbiya Aksakal ${ }^{2}$, Süleyman Karakoyun ${ }^{3}$ \\ ${ }^{1}$ Erzurum Education and Research Hospital, Department of Cardiology, Erzurum, Turkey \\ ${ }^{2}$ Atatürk University Medical School, Department of Cardiology, Erzurum, Turkey \\ ${ }^{3}$ Koşuyolu Heart Hospital, Department of Cardiology, Istanbul, Turkey
}

\section{ABSTRACT}

Objectives: The objective of the study was to evaluate the relationship of epicardial fat thickness (EFT) assessed by echocardiography with atrial fibrillation (AF) in a clinical setting.

Materials and methods: The study consisted of $58 \mathrm{AF}$ patients who underwent echocardiography and a control group of 22 participants. The EFT thickness was measured on the free wall of the right ventricle from the parasternal long-axis view. The association between EFT and AF was studied by adjusting the risk factors for AF, including structural valvular diseases and multiple risk factors.

Results: EFT was significantly increased in patients with AF as compared to participants in the control group $(6.5 \pm$ $1.2 \mathrm{~mm}$ vs. $5.8 \pm 1.0 \mathrm{~mm}, \mathrm{p}=0.01)$. In subgroup analysis of different types of AF, EFT was significantly increased in permanent $\mathrm{AF}$ in relation to paroxysmal and persistent $\mathrm{AF}(6.8 \pm 0.9 \mathrm{~mm}$ vs. $6,0 \pm 1.2 \mathrm{~mm}$ and $5.8 \pm 1.2$ respectively). In addition, EFT measurements were comparable between sinus rhythm, paroxysmal and persistent AF.

Conclusions: Epicardial fat thickness measured by echocardiography seems to be associated with the chronicity of AF. J Clin Exp Invest 2012; 3(1): 13-17

Key words: Epicardial fat, echocardiography, atrial fibrillation

\section{INTRODUCTION}

Atrial fibrillation (AF) is one of the most common cardiac arrhythmia. ${ }^{1}$ It is well established that obesity is associated with high incidences of cardiovascular disease. ${ }^{2}$ Obesity and/or metabolic syndrome are independent risk factors for AF, with the features of: i) elevated end-diastolic filling pressures that lead to atrial dilatation, ii) activation of neuroendocrine systems and inflammatory response, both of which have potential roles in the pathophysiology of $\mathrm{AF}^{3-5}$ Recent studies have focused on the relationship be-

\section{ÖZET}

Amaç: Çalışmamızın amacı ekokardiyografi ile ölçülen epikardiyal yağ doku (EYD) kalınlığı ile atriyal fibrilasyon (AF) ilişkisini araştırmaktır.

Gereç ve yöntem: Çalışma grubu ayrıntılı ekokardiyografi yapılan $58 \mathrm{AF}$ hastası ve 22 kontrol hastasından oluşmaktadır. EYD kalınlığı parasternal uzun eksen görüntüsünden elde edilen sağ ventrikül serbest duvarından ölçüldü. EYD ile AF arasındaki ilişki, AF için yapısal kalp hastalığı ve çoklu risk faktörlerinin düzenlenmesi ile incelenmiştir.

Bulgular: Kontrol grubu ile karşıllaştıııldığında EYD AF hastalarda belirgin olarak kalındır $(6.5 \pm 1.2 \mathrm{~mm}$ vs $5.8 \pm$ $1.0 \mathrm{~mm}, \mathrm{p}=0.01)$. Farklı AF tiplerinin alt grup analizinde, EYD permanent AF hastalarında paroksismal ve persistant $\mathrm{AF}$ hastalarından daha kalın saptanmıştır (sırasıyla $6.8 \pm 0.9 \mathrm{~mm}$ vs $6,0 \pm 1.2 \mathrm{~mm}$ and $5.8 \pm 1.2$ ). Ayrica, EYD kalınlığı sinüs ritmi, paroksismal ve persistent AF da benzer bulunmuştur.

Sonuç: Ekokardiyografi ile ölçülen epikardiyal yağ doku kalınlığı atriyal fibrilasyonun süresi ile ilişkilidir.

Anahtar kelimeler: Epikardiyal yağ doku, ekokardiyogra$\mathrm{fi}$, atrial fibrilasyon

tween body fat distribution and the risk of cardiovascular diseases, demonstrating that visceral adipose tissue appears to play a key role in the genesis of $A F^{6-16}$ Epicardial fat thickness (EFT), a form of adipose tissue located around the heart, has been shown to be an important source of inflammatory mediators and potentially underlies the pathophysiology of AF. ${ }^{17}$ With the development of technology and major advances in calculating the pericardial fat measurement with computerized tomography, the significant association between pericardial fat volume and AF and its role in the pathogenesis of 
AF was shown in a recent study..$^{18}$ Although the diagnostic value of $C T$ in measuring the pericardial fat is high, the echocardiographic epicardial fat measurement in both clinical and research scenarios has several advantages, including its low cost, easy accessibility, rapid applicability, and good reproducibility. Thus, the objective of the index observational study was to evaluate the relationship between epicardial fat thickness assessed by echocardiography and the presence and severity of AF in a clinical setting.

\section{MATERIALS AND METHODS}

\section{Patients}

A total of 58 patients with AF were enrolled. The patient group consisted of 34 females and 24 males (mean age $61.3 \pm 10.1$ years). Diagnosis of AF was made based on the electrocardiogram. Clinical features of patients with AF (if any) were recorded as structural valvular diseases (native or prosthetic valvular heart diseases, including severe stenosis and or regurgitation), coronary artery disease (CAD), and atherosclerotic risk factors (diabetes mellitus, hypertension, smoking). Patients with poor echocardiographic windows were excluded.

\section{Controls}

Twenty-two patients, who were in sinus rhythm, age and sex matched, were included in this study. Clinical features of the control group were recorded as history of CAD (history of percutaneous coronary intervention and coronary artery bypass surgery), structural valvular diseases (native or prosthetic valvular heart diseases including severe stenosis and/or regurgitation), and atherosclerotic risk factors such as diabetes mellitus, hypertension, and smoking.

\section{Echocardiography and epicardial fat measurement}

All participants underwent a complete transthoracic echocardiography according to the American Society of Echocardiography guidelines. Transthoracic echocardiographic studies were performed, with the patient in the left lateral position, using the GE-Vivid 7 system (GE-Vingmed Ultrasound AS, Horten, Norway). Echocardiography was performed by a cardiologist who had substantial clinical expertise in echocardiography and who was unaware of the clinical data (M.K.). All data were transferred to a workstation for further offline analysis (EchoPAC 6.1; GE Vingmed Ultrasound AS). The EFT was measured on the free wall of the right ventricle from the parasternal long-axis view, as previously described and validated19. EFT was described as an echo-free space in the pericardial layers on the two dimensional echocardiography, and its thickness was measured perpendicularly on the free wall of the right ventricle at end-systole for 3 to 10 cardiac cycles. The measurement was performed at a point on the free wall of the right ventricle along the midline of the ultrasound beam, perpendicular to the aortic annulus. In order to increase the confidence in the results, EFT measurement was performed at two different moments and the percentage of RR interval with the least amount of motion was used.

Standard two-dimensional echocardiographic evaluation of left atrial anteroposterior diameter was measured at end systole in the parasternal longaxis view. Left atrial echocardiographic volume was calculated using the area length model by tracing the endocardial edges of the left atrial area in two and four chamber views. Left ventricular ejection fraction (LVEF) was measured using the Simpson method. An LVEF of $<50 \%$ was accepted as abnormal.

\section{Statistical analysis}

Continuous variables are expressed as mean $\pm S D$. The level of significance was 0.05 . The KolmogorovSmirnov test was used for the normality test of all variables. To compare continuous variables, Independent Student $t$ test/analysis of variance or the Mann-Whitney U/Kruskall-wallis test was used, and to compare categorical variables the chi-square test was used. Correlations between variables were tested by Pearson or Spearman correlation tests where appropriate. Statistical analyses were performed using SPSS, version 15.0 for Windows.

\section{RESULTS}

Fifty-eight patients (24 males; mean age $61.3 \pm 10.1$ years) with $\mathrm{AF}$ and a control group of 22 participants with sinus rhythm (15 males; mean age $58.7 \pm 11.4$ years) were included in this observational study. According to the AF classification, the AF group consisted of 26 patients with permanent $A F, 15$ patients with persistent $A F$, and 17 patients with paroxysmal AF. Baseline demographic and clinical characteristics of the AF and sinus rhythm groups are presented in table 1.

While age, gender, atherosclerotic risk factors, $C A D$, valvular heart disease, anthropometric measurements (BMI and BSA) matched well between AF patients and the control group, there were statistically significant differences with regard to the in- 
creased left atrial volume index, left atrial diameter, epicardial fat thickness and reduced LVEF in the AF group.

Table 1. Baseline clinical characteristics of study participants

\begin{tabular}{|c|c|c|c|}
\hline Variable & $\begin{array}{l}\text { Sinus rhythm } \\
(n=22)\end{array}$ & $\begin{array}{c}\text { AF } \\
(n=58)\end{array}$ & $p$ value \\
\hline Age, yrs & $58.7 \pm 11.4$ & $61.3 \pm 0.1$ & 0.58 \\
\hline Gender, male no. & $15(68 \%)$ & $24(41 \%)$ & 0.34 \\
\hline \multicolumn{4}{|l|}{$\begin{array}{l}\text { Subgroup of AF, } \\
\text { no. }(\%)\end{array}$} \\
\hline Paroxysmal & & $17(29 \%)$ & \\
\hline Persistant & & $15(26 \%)$ & \\
\hline Permenant & & $26(45 \%)$ & \\
\hline Hypertension, \% & 36 & 41 & 0.91 \\
\hline Diabetes Mellitus, \% & 13 & 16 & 0.83 \\
\hline Smoking, \% & 36 & 31 & 0.66 \\
\hline $\begin{array}{l}\text { Coronary Artery } \\
\text { Disease, \% }\end{array}$ & 41 & 35 & 0.71 \\
\hline $\begin{array}{l}\text { Valvular Heart } \\
\text { Disease, \% }\end{array}$ & 13 & 30 & 0.13 \\
\hline $\operatorname{BSA}\left(m^{2}\right)$ & $1.88 \pm 0.18$ & $1.90 \pm 0.16$ & 0.77 \\
\hline $\mathrm{BMI}, \mathrm{kg} / \mathrm{m}^{2}$ & $29.3 \pm 4.0$ & $28 \pm 4.3$ & 0.38 \\
\hline LAV-i, $\mathrm{ml} / \mathrm{m}^{2}$ & $29.6 \pm 5.3$ & $43.4 \pm 7.5$ & $<0.001$ \\
\hline LA diameter, mm & $37.5 \pm 3.2$ & $44.1 \pm 4.2$ & $<0.001$ \\
\hline LVEF, \% & $62.3 \pm 3.6$ & $57.8 \pm 3.3$ & $<0.001$ \\
\hline EFT, mm & $5.8 \pm 1.0$ & $6.5 \pm 1.2$ & 0.01 \\
\hline
\end{tabular}

BSA: body surface area; BMI: body mass index; LAV-i: left atrial volume index; LVEF: left ventricular ejection fraction; EFT:epicardial fat thickness; AF: Atrial Fibrillation

As Figure 1 and table 2 demonstrates, EFT was significantly increased in patients with $A F$ as compared to participants in the control group (6.5 $\pm 1.2 \mathrm{~mm}$ vs $5.8 \pm 1.0 \mathrm{~mm}, \mathrm{p}=0.01)$. In subgroup analysis of different types of AF, EFT was significantly increased in permanent $A F$ in relation to paroxysmal and persistent AF $(6.8 \pm 0.9 \mathrm{~mm}$ vs $6.0 \pm$ $1.2 \mathrm{~mm}$ and $5.8 \pm 1.2$ respectively). In addition, EFT measurements were comparable between sinus rhythm, paroxysmal and persistent AF $(5.8 \pm 1.0,6.0$ $\pm 1.2 \mathrm{~mm}$ and $5.8 \pm 1.2$ respectively).

\section{Epicardial fat thickness and left atrial size}

Consistent with previous studies, left atrial diameter and left atrial volume index were both larger in AF patients in relation to sinus rhythm $(37.5 \pm 3.2 \mathrm{~mm}$ vs. $44.1 \pm 4.2 \mathrm{~mm}$; $p<0.001,29.6 \pm 5.3 \mathrm{ml}$ vs. $43.4 \pm$
$7.5 \mathrm{ml}, \mathrm{p}=<0.001$ respectively). EFT was positively correlated with left atrial enlargement measured with left atrial volume index $(r=0.33, p=0.01)$. There was no significant association of EFT with left atrial diameter $(r=0.23, p=0.06)$ and left ventricular ejection fraction $(r=-0.08, p=0.71)$ (Table 3$)$.

Table 2. Epicardial fat thickness values between sinus rhythm and AF subgroups

\begin{tabular}{ccccc}
\hline Variable & $\begin{array}{c}\text { Sinus } \\
\text { Rhythm }\end{array}$ & $\begin{array}{c}\text { Paroxysmal } \\
\text { AF }\end{array}$ & $\begin{array}{c}\text { Persistent } \\
\text { AF }\end{array}$ & $\begin{array}{c}\text { Permanent } \\
\text { AF }\end{array}$ \\
\hline EFT $(\mathrm{mm})$ & $5.8 \pm 1.0$ & $6.0 \pm 1.2$ & $5.8 \pm 1.2$ & $6.8 \pm 0.9$ \\
\hline
\end{tabular}

EFT: Epicardial fat thickness; AF: Atrial Fibrillation

Table 3. Correlation between epicardial fat volume and left atrial size/left ventricular ejection fraction

\begin{tabular}{lcc}
\hline Parameters & r value & $p$ value \\
\hline EFT-LAVi & 0.33 & 0.01 \\
EFT-EF & 0.08 & 0.71 \\
EFT-LAd & 0.23 & 0.06 \\
\hline
\end{tabular}

$\mathrm{LAV}-\mathrm{i}=$ left atrial volume index; $\mathrm{LVEF}=$ left ventricular ejection fraction; EFT= epicardial fat thickness, LAd= Left atrium anteroposterior dimension

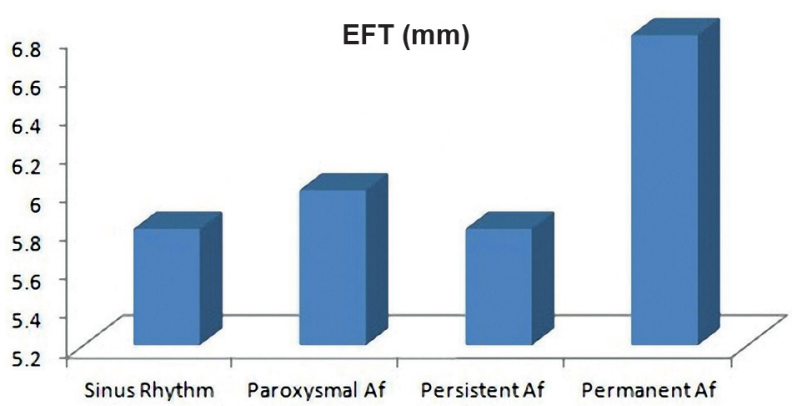

Figure 1. Epicardial fat thickness in sinus rhythm and atrial fibrillation subgroups

\section{DISCUSSION}

The present study provides insights into the relationship between echocardiographic assessment of increased EFT and the presence and severity of AF. We demonstrated that EFT was significantly increased in only patients with permanent AF and this result might be speculated that, EFT could be associated with the chronicity of AF. To the best of our knowledge, this is the first study to examine the association between epicardial fat measured with echocardiography and AF. Indeed, AF patients or patients with frequent atrial ectopy or atrial tachycardia are associated with higher C-reactive protein 
that is reflected in the relationship between inflammatory mechanisms and AF pathogenesis. ${ }^{20}$ The pathophysiology of $A F$ is complex, hovering around the concepts of structural, molecular and genetic changes. Although the exact pathophysiology of AF is unknown, one of the responsible mechanisms is thought to be inflammation. ${ }^{21}$ It has been demonstrated that patients with AF have elevated levels of inflammatory cytokines, which has been shown to be an indication of the severity and persistence of AF.22 Today, it is well established that epicardial adipose tissue can be considered as a form of visceral adipose tissue. ${ }^{23}$ Visceral adipose tissue is considered as an endocrine organ that is able to produce and release a variety of inflammatory cytokines in order to produce an enhanced inflammatory burden in cardiovascular diseases. ${ }^{24-27}$ Adipose tissue can produce both proinflammatory and protective factors called adipocytokines in EFT, which can produce cardiac abnormalities by neurohormonal activation, cytokine production and inflammation. 28-34 Since the epicardial adipose tissue is in the vicinity of the atrium, these cytokines can directly produce myocardial remodeling and enhance local inflammation between epicardial fat tissue and neighboring atrial wall. In previous studies, EFT was generally measured with CT and MRI. EFT assessed by echocardiography has recently been advanced as a practical method for evaluating the risk of visceral adiposity and cardiometabolic risk. ${ }^{19,35}$ When compared with MRI and CT, echocardiographic assessment of epicardial fat has both advantages and disadvantages. Echocardiography is more readily available and less expensive than either MRI or CT. Unlike CT, echocardiography has the advantage of not exposing patients to radiation or to contrast media. Therefore, echocardiography may be more practical for longitudinal population studies of EFT and ultimately for clinical settings. However, echocardiography only samples a tomographic slice of the epicardial and pericardial fat and may not reflect the total volume. Nevertheless, EFT measured by echocardiography correlates highly with MRI determined epicardial fat and intra-abdominal visceral adipose tissue. ${ }^{36}$ Notwithstanding the fact that the role of echocardiographic measurements in AF has limitations, our study provides support to the notion that epicardial fat measurement with echocardiography is correlated with the severity and duration of AF. This result is inconsistent with the study by Al Chekakie et al. ${ }^{18}$ In their study, pericardial fat volume was measured using computerized tomography and it revealed that it is highly associated with paroxysmal and persistent AF, independent of traditional risk factors, including left atrial enlargement.
Moreover, their study proposed that the volume of pericardial fat may play a role in the pathogenesis of AF. However, in our study we could not demonstrate any significant differences between patients with sinus rhythm and paroxysmal/persistent AF in regarding EFT. Permanent AF patients had significantly increased EFT than paroxysmal/persistent $\mathrm{AF}$ and sinus rhythm patients. We proposed that, the absence of significant difference in the EFT between the two study groups (paroxysmal and persistent AF) may be due to small size of patients in these groups.

Some limitations of our study are small number of participants, especially paroxysmal and persistent AF. The slices obtained from images of each patient were possibly slightly different. However, these factors would have affected the results equally in both patient and control groups.

In conclusion, our data indicate that epicardial fat measured with echocardiography seems to be associated with the presence and severity of AF. Measures of epicardial fat in larger samples with longitudinal assessment of development and its association with $\mathrm{AF}$ are needed to confirm these findings. Given the importance of AF to public health, enhanced research in this area, which could yield new imaging and measurement techniques, is imperative.

\section{REFERENCES}

1. Camm AJ, Kirchhof P, Lip GY, et al. Guidelines for the management of atrial fibrillation: the Task Force for the Management of Atrial Fibrillation of the European Society of Cardiology (ESC). Eur Heart J 2010; 31 (19) :2369-429.

2. Kenchaiah S, Evans JC, Levy D, et al. Obesity and the risk of heart failure. N Engl J Med 2002; 347 (5):30513.

3. Nicolaou VN, Papadakis JE, Karatzis EN, et al. Impact of the metabolic syndrome on atrial size in patients with new-onset atrial fibrillation. Angiology 2007; 58 (1):21-5.

4. Morricone L, Malavazos AE, Coman C, et al. Echocardiographic abnormalities in normotensive obese patients: relationship with visceral fat. Obes Res 2002; 10:489-98.

5. Kopelman PG. Obesity as a medical problem. Nature 2000; 404 (6778):635-43.

6. Kim YM, Guzik TJ, Zhang YH, et al. A myocardial Nox2 containing $\mathrm{NAD}(\mathrm{P}) \mathrm{H}$ oxidase contributes to oxidative stress in human atrial fibrillation. Circ Res 2005; 97 (7):629-36.

7. Mihm MJ, Yu F, Carnes CA, et al. Impaired myofibrillar energetics and oxidative injury during human atrial fibrillation. Circulation 2001; 104(2):174-80. 
8. Chung MK, Martin DO, Sprecher D, et al. C-reactive protein elevation in patients with atrial arrhythmias: inflammatory mechanisms and persistence of atrial fibrillation. Circulation 2001; 104 (24):2886-91.

9. Kim YH, Lim DS, Lee JH, et al. Gene expression profiling of oxidative stress on atrial fibrillation in humans. Exp Mol Med 2003; 35(5):336-49.

10. Ford ES, Mokdad AH, Giles WH, et al. The metabolic syndrome and antioxidant concentrations: findings from the Third National Health and Nutrition Examination Survey. Diabetes 2003; 52 (9):2346-52.

11. Ridker PM, Buring JE, Cook NR, et al. C-reactive protein, the metabolic syndrome, and risk of incident cardiovascular events: an 8-year follow-up of 14719 initially healthy American women. Circulation 2003; 107 (3):391-7.

12. Boos CJ, Lip GY. The role of inflammation in atrial fibrillation. Int J Clin Pract 2005; 59:870-2.

13. Engelmann MD, Svendsen JH. Inflammation in the genesis and perpetuation of atrial fibrillation. Eur Heart J 2005; 26:2083-92.

14. Boos CJ, Anderson RA, Lip GY. Is atrial fibrillation an inflammatory disorder? Eur Heart J 2006; 27 (20):13649.

15. Liu T, Li L, Korantzopoulos P, et al. Meta-analysis of association between C-reactive protein and immediate success of electrical cardioversion in persistent atrial fibrillation. Am J Cardiol 2008; 101(12):1749-52.

16. Mazurek T, Zhang L, Zalewski A, et al. Human epicardial adipose tissue is a source of inflammatory mediators. Circulation 2003; 108 (20):2460-6.

17. Lin YK, Chen YJ, Chen SA. Potential atrial arrhythmogenicity of adipocytes: implications for the genesis of atrial fibrillation. Med Hypotheses 2010; 74 (6):10269.

18. Al Chekakie MO, Welles CC, Metoyer R, et al. Pericardial fat is independently associated with human atrial fibrillation. J Am Coll Cardiol 2010; 56 (10):784-8.

19. lacobellis G, Assael F, Ribaudo MC, et al. Epicardial fat from echocardiography: a new method for visceral adipose tissue prediction. Obes Res 2003; 11 (2):30410.

20. Liuba I, Ahlmroth H, Jonasson L, et al. Source of inflammatory markers in patients with atrial fibrillation. Europace 2008; 10 (7):848-53.

21. Korantzopoulos P, Kolettis TM, Galaris D, et al. The role of oxidative stress in the pathogenesis and perpetuation of atrial fibrillation. Int $\mathrm{J}$ Cardiol 2007; 115 (2):135-43.

22. Gualillo O, Gonzalez-Juanatey JR, Lago F. The emerging role of adipokines as mediators of cardiovascular function: physiologic and clinical perspectives. Trends Cardiovasc Med 2007; 17 (8):275-83.
23. Lau DC, Dhillon B, Yan H, et al. Adipokines: molecular links between obesity and atheroslcerosis. Am J Physiol Heart Circ Physiol 2005; 288 (5):H2031-41.

24. Fontana L, Eagon JC, Trujillo ME, et al. Visceral fat adipokine secretion is associated with systemic inflammation in obese humans. Diabetes 2007; 56 (4):1010-3.

25. Lago F, Dieguez C, Gomez-Reino J, et al. The emerging role of adipokines as mediators of inflammation and immune responses. Cytokine Growth Factor Rev 2007; 18 (3):313-25.

26. Bastelica D, Morange P, Berthet B, et al. Stromal cells are the main plasminogen activator inhibitor-1-producing cells in human fat: evidence of differences between visceral and subcutaneous deposits. Arterioscler Thromb Vasc Biol 2002; 22 (1):173-8.

27. Karlsson C, Lindell K, Ottosson M, et al. Human adipose tissue expresses angiotensinogen and enzymes required for its conversion to angiotensin II. J Clin Endocrinol Metab 1998; 83 (11):3925-9.

28. Fukuhara A, Matsuda M, Nishizawa M, et al. Visfatin: a protein secreted by visceral fat that mimics the effects of insulin. Science 2005; 307 (1):426-30.

29. Daviaud D, Boucher J, Gesta S, et al. TNFalpha upregulates apelin expression in human and mouse adipose tissue. FASEB J 2006; 20 (9):1528-30.

30. Yang RZ, Lee MJ, Hu H, et al. Identification of omentin as a novel depot-specific adipokine in human adipose tissue: possible role in modulating insulin action. Am J Physiol Endocrinol Metab 2006; 290 (6):E1253-61.

31. Bozaoglu K, Bolton K, McMillan J, et al. Chemerin is a novel adipokine associated with obesity and metabolic syndrome. Endocrinology 2007; 148 (10):4687-94.

32. Fain JN, Madan AK, Hiler ML, et al. Comparison of the release of adipokines by adipose tissue, adipose tissue matrix, and adipocytes from visceral and subcutaneous abdominal adipose tissues of obese humans. Endocrinology 2004; 145 (5):2273-82.

33. lacobellis G, Ribaudo MC, Assael F, et al. Echocardiographic epicardial adipose tissue is related to anthropometric and clinical parameters of metabolic syndrome: a new indicator of cardiovascular risk. J Clin Endocrinol Metab 2003; 88 (11):5163-8.

34. lacobellis G, Leonetti F. Epicardial adipose tissue and insulin resistance in obese subjects. J Clin Endocrinol Metab 2005; 90 (11):6300-2.

35. lacobellis G, Willens HJ. Echocardiographic epicardial fat: a review of research and clinical applications. J Am Soc Echocardiogr 2009; 22 (12):1311-9.

36. Fox CS, Gona P, Hoffmann U, et al. Pericardial fat, intrathoracic fat, and measures of left ventricular structure and function: the Framingham Heart Study. Circulation 2009; 119 (12):1586-91. 